\title{
Direct and residual effect of zinc and zinc amended organic manures on the zinc nutrition of field crop
}

\author{
Shelley Gupta and Kalpana Handore \\ PGMCOE, Wagholi, Pune
}

\begin{abstract}
Zinc (Zn) deficiency is the most widespread micronutrient disorder in rice (Oryza sativa) The objective of this paper was to examine alternative evaluation methods and to identify the most informative traits that would provide realistic information for rice breeders and to map quantitative trait loci (QTLs) associated with tolerance The most severe symptom in the field was high plant mortality. Zinc interfered with translocation of iron from roots to above ground parts of Glycine max. (L.) Merrill var. Hawkeye. During periods in which zinc impeded iron translocation, it also suppressed the production of reductant by roots. Addition of iron, as a ferric metal chelate (iron ethylenediaminedihydroxyphenylacetic acid), to the growth medium overcame the interference of zinc. In the root epidermis, potassium ferricyanide formed a precipitate (Prussian blue) with ferrous iron derived from the previously supplied iron ethylenediaminedihydroxyphenylacetic acid. The reduction of ferric iron was suppressed by zinc. In a field experiment on silt loam calcareous soil, the direct and residual effect of zinc and zinc amended organic manures were studied on rice (Oryza sativa L.) followed by barley (Hordeum vulgare L.) and rice respectively. Visual $\mathrm{Zn}$ deficiency symptoms were observed on rice in on zinc plots. Application of zinc significantly increased the crop yield. The magnitude of yield response was intensified where zinc was applied in conjunction with organic manures. The highest $\mathrm{Zn}$ uptake in these three crops was recorded at 5 $\mathrm{kg} \mathrm{Zn}$ amended with $10 \mathrm{t}$ compost /ha.
\end{abstract}

Keyword- Oryza, Zinc Sulphate, Organic Manure, Organometallic Complexes, Calcerous soil

\section{Introduction}

Among different micronutrients, the deficiency of zinc is widespread in Indian soil [2]. Micronutrients delineation in soils and plants revealed that 70 to $80 \%$ soils in calcareous belt are deficient in available zinc (Anonymous, 198081) where apparent zinc deficiency symptoms have been observed on several field crops [7]. Increasing demand of zinc sulphate to migrate the zinc problem is leading a continuous rise in its price. Hence it was felt necessary to enhance the efficiency of native and applied $\mathrm{Zn}$ in such soils where $\mathrm{Zn}$ availability is an obstacle. The present investigation was therefore, initiated to study the direct and residual effect of zinc and amended organic manure on crops grown in succession.

\section{Material and Method}

A field experiment was conducted on a silt loam calcareous soil. There were fifteen treatments as shown in table 1. Two sources of manure i.e. farm yard manure (FYM) and compost were used. This organic manure were mixed with zinc sulphate, slightly moistened, kept in polythene bags for 10 days to complete the chelation reaction and then applied in appropriate treatment plots and mixed with plough layer soil. The treatments were replicated thrice in a randomized block design. Rice variety "Sita" was taken as first test crop followed by barley variety "DL 36" and rice variety "Sita" in order to study the residual effect of treatment applied with first crop. A basal dose of $110 \mathrm{~kg} \mathrm{~N}, 60 \mathrm{~kg}$ P2O5and $50 \mathrm{~kg} \mathrm{K2O} / \mathrm{ha}$ in rice and $60 \mathrm{~kg} \mathrm{~N}, 0 \mathrm{~kg} \mathrm{P2O5}$ and $30 \mathrm{~kg} \mathrm{~N} 2 \mathrm{O} / \mathrm{ha}$ in barley was applied as urea, single super phosphate and muriate of potash, respectively. In third crop (rice) the levels of $\mathrm{N}$, $\mathrm{P} 2 \mathrm{O} 5$ and $\mathrm{K} 2 \mathrm{O}$, and corresponding carriers were same as in first crop rice. The grain and straw yields were recorded. The plant samples were washed in acidified detergent solutions, rinsed in distilled water and dried in oven at $650 \mathrm{C}$. the plant samples were pulverized in a waring blender, digested in tri- acid mixture [6]The initial soil sample collected at the start of the experiment was analyzed for some important characteristics [3]Available $\mathrm{Zn}$ was extracted with DTPA as per procedure of [4]. The $\mathrm{pH}, \mathrm{EC}, \mathrm{OC}$, free $\mathrm{CaCO} 3$ and available $\mathrm{Zn}$ were $8.6,0.58$, mhos $/ \mathrm{cm}, 0.46 \%$, $36 \%$ and .58 PPM, respectively. The zinc content in soil and plants extract was determined with the help of atomic absorption spectrophotometer. DTPA extractable $\mathrm{Zn}$ in FYM and compost was 10 and 15 PPM, respectively.

\section{Results and Discussion}

Direct effect on rice (1st crop): The grain and straw yields as influenced by $\mathrm{Zn}$ and $\mathrm{Zn}$ amended organic manure is presented in Table 1. It is evident that applications of Zinc alone or in combination with organic manure significantly increase the grain and straw yields over control. The grain yield response ranged from 4.2 to19.5 and straw yield response from 7.7 to $35.4 \mathrm{q} / \mathrm{ha}$. Mixing of $2.5 \mathrm{~kg} \mathrm{Zn}$ either with 50-q FYM/ compost or100-q FYM/ compost produced the similar yields. The grain yield response obtained due to amendment of $2.5 \mathrm{~kg} \mathrm{Zn}$ with $50 \mathrm{q}$ FYM/ compost was equivalent to $5 \mathrm{~kg} \mathrm{Zn} /$ ha application. Hence with the use of organic manure the optimum level of $\mathrm{Zn}$ can be reduced to about $50 \%$. This beneficial effect of organic 
mangers may be attributed to the formation of organometallic complexes with $\mathrm{Zn}$, which resulted in the increase of its efficiency. These results are in accordance with the findings of several workers $[5,7,1,8]$ The $\mathrm{Zn}$ uptake in grain and straw ranged from 41.2 to 111.2 and 81.2 to $244.1 \mathrm{~g} / \mathrm{ha}$ respectively. The total $\mathrm{Zn}$ uptake at 2.5 $\mathrm{kg} \mathrm{Zn}+50 \mathrm{q}$ FYM is at par with $2.5 \mathrm{~kg} \mathrm{Zn}+100 \mathrm{q}$ $\mathrm{FYM} /$ compost $+2.5 \mathrm{~kg} \mathrm{Zn/ha}$. It is also interesting to record that total $\mathrm{Zn}$ uptake in $5 \mathrm{~kg}$ $\mathrm{Zn}+100 \mathrm{q} F \mathrm{FM} /$ compost treatment is identical to $2.5 \mathrm{~kg} \mathrm{Zn} \mathrm{mixed} \mathrm{with} 100 \mathrm{q}$ FYM/ compost/ha. The experimental soil was deficient in available $\mathrm{Zn}$ as its value was below the critical limit of 0.78 PPM [9]. Residual effect on barely (2nd crop) and rice (3rd crop): the residual effect of $\mathrm{Zn}$ and $\mathrm{Zn}$ amended organic manure on Barley is shown in Table 2. The residual response in grain and straw yields of barley ranged from 1.4 to 9.5 and 1.3 to $15.1 \mathrm{q} /$ ha respectively. It was further observed that the residual value of either $100 \mathrm{q} F Y M+2.5$ $\mathrm{kg} \mathrm{Zn}$ or $100 \mathrm{q}$ composite $+2.5 \mathrm{~kg} \mathrm{Zn/ha} \mathrm{was}$ equivalent $50 \mathrm{q} F Y M+5 \mathrm{~kg} \mathrm{Zn} / \mathrm{ha}$ wit respect to grain and straw yields. However maximum grain and straw yields response was recorded at $100 \mathrm{q}$ composite $+5 \mathrm{~kg} \mathrm{Zn/ha} \mathrm{level} \mathrm{with} \mathrm{corresponding}$ value of $9.5 \& 15.1 \mathrm{q} / \mathrm{ha}$ respectively. The uptake of $\mathrm{Zn}$ progressively increase with increasing level of $\mathrm{Zn}$ and organic manure showing the highest value of 292.6 at 100 q composite $+5 \mathrm{~kg} \mathrm{Zn} / \mathrm{ha}$ treatment. The residual effect of these treatments was studied on rice as third crop (Table 3). The rice variety was same that was grown as $1 \mathrm{st}$ crop but the yield was lower as compared to 1st crop. This low yield is due to prolonged submergence of field as a result of flood during the early period of crop growth, which accrued poor tilering. The grain and straw yield response ranged from 0.3 to 9.1 and 0.3 to $19.2 \mathrm{q} /$ ha respectively. The magnitude of response was quite low as compared to 1st rice crop. The residual value of $\mathrm{Zn}$ and $\mathrm{Zn}$ amended organic manure was still higher than with respect to yields and $\mathrm{Zn}$ uptake.
The total $\mathrm{Zn}$ uptake ranged from 94.8 to 241.2 $\mathrm{g} / \mathrm{ha}$. The highest $\mathrm{Zn}$ uptake was noted in the treatment receiving $100 \mathrm{q}$ composed $+5 \mathrm{~kg} \mathrm{Zn}$ /ha. From this study it may be inferred that the residual value of soil applied amending it with organic manure can enhance $\mathrm{Zn}$.

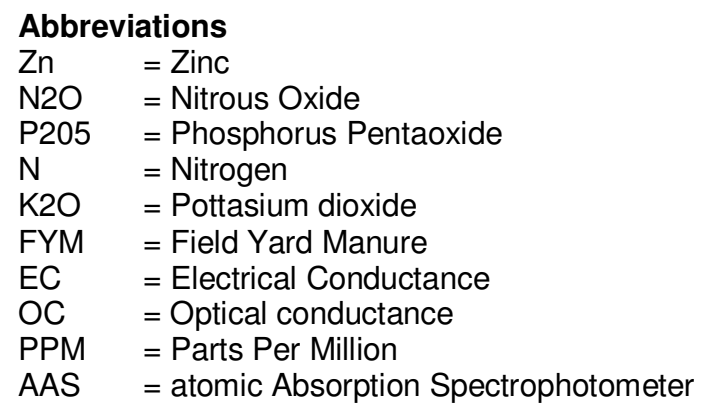

\section{References}

[1] Gupta V.K, Gupta A.P. and Raj H. (1983) Indian J. agric. Sci. 53(59): 826-830.

[2] Katyal J.C. and Agarwala S.c. (1982) Micronutrient Research in India. Fert. News. 27(2): 85-86.

[3] Jackson M. (1967) Soil chemical analysis. Prentice Hall of India, Pvt. Ltd., New Delhi.

[4] Lindsay W.L. and Norvell W.A. (1978) Soil Sci. Soc. Am. J. 42: 421-428.

[5] Miller B.F., Lindseed W.L. and Parsa A.A. (1969) Use of poultry manure for correction of zinc and iron deficiencies in plants. Proc. Conf. On animal.

[6] Piper C.S. (1966) Soil and plant analysis. Hans Publishers, Bombay.

[7] Sakal R. and Singh A.P. (1979) Zinc hunger in Kharif crop of north Bihar. Indian Fmg. 28 : 3-5.

[8] Singh A.P., Sakal R. and Singh B.P. (1983) Pl. and soil. 73 : 315-322.

[9] Sakal R., Singh B.P. and Singh A.P. (1982) Pl. and soil. 66: 129-132. 
Table 1: Direct effect of zinc and organic manures on rice yields and zinc uptake

\begin{tabular}{|c|c|c|c|c|c|}
\hline Treatment & $\begin{array}{l}\text { Yield } \\
\text { q/ha }\end{array}$ & $\begin{array}{l}\text { Zinc } \\
\text { uptake }\end{array}$ & Total & & \\
\hline \multicolumn{6}{|l|}{ g/ha } \\
\hline Grain & Straw & Grain & Straw & & \\
\hline Control & 22.5 & 45.3 & 41.2 & 81.2 & 124.4 \\
\hline $2.5 \mathrm{~kg}$ zinc/ha & 33.7 & 66.7 & 70.2 & 135 & 205.2 \\
\hline $5.0 \mathrm{~kg}$ zinc/ha & 36.3 & 71.8 & 81.1 & 169.4 & 252.5 \\
\hline 5t FYM/ha & 27.3 & 53 & 55.5 & 111.2 & 166.6 \\
\hline $5 \mathrm{t} \mathrm{FYM} \mathrm{+} \mathrm{2.5kg} \mathrm{zinc/ha}$ & 38 & 75.2 & 85.5 & 205.3 & 290.8 \\
\hline $5 \mathrm{t} \mathrm{FYM} \mathrm{+} 5.0 \mathrm{~kg}$ zinc/ha & 42 & 80.7 & 100.4 & 230.9 & 331.3 \\
\hline 10t FYM/ha & 29.7 & 59.7 & 62.3 & 140.7 & 203 \\
\hline 10t FYM + 2.5kg zinc/ha & 39.3 & 78.3 & 85.5 & 231.2 & 318.7 \\
\hline 10t FYM + $5.0 \mathrm{~kg}$ zinc/ha & 33.5 & 69.8 & 81.8 & 211.2 & 295.4 \\
\hline 5t Compost/ha & 30.2 & 57.8 & 61.3 & 115.9 & 177.2 \\
\hline $5 \mathrm{t}$ Compost $+2.5 \mathrm{~kg}$ & 39.7 & 77 & 88.6 & 209.5 & 298.1 \\
\hline \multicolumn{6}{|l|}{ zinc/ha } \\
\hline $5 \mathrm{t}$ Compost $+5.0 \mathrm{~kg}$ & 39 & 77.5 & 99.4 & 217.7 & 317.1 \\
\hline \multicolumn{6}{|l|}{ zinc/ha } \\
\hline 10t Compost/ha & 31.8 & 64.3 & 68 & 139.6 & 207.6 \\
\hline 10t Compost $+2.5 \mathrm{~kg}$ & 40.2 & 79.2 & 93.6 & 237.9 & 331.5 \\
\hline \multicolumn{6}{|l|}{ zinc/ha } \\
\hline $10 \mathrm{t}$ Compost $+5.0 \mathrm{~kg}$ & 38 & 75 & 111.2 & 244.9 & 355.3 \\
\hline \multicolumn{6}{|l|}{ zinc/ha } \\
\hline C.D. at $5 \%$ & 1.3 & 8.1 & 14.4 & 31.2 & 34.7 \\
\hline
\end{tabular}


Table 2: Residual effect of zinc and organic manures on barley (second crop) yields and zinc uptake

\begin{tabular}{|c|c|c|c|c|c|}
\hline \multirow[t]{2}{*}{ Treatment } & \multicolumn{2}{|c|}{ Yield q/ha } & \multicolumn{2}{|c|}{ Zinc uptake g/ha } & \multirow[t]{2}{*}{ Total } \\
\hline & Grain & Straw & Grain & Straw & \\
\hline Control & 31 & 47.4 & 82.2 & 61.8 & 144 \\
\hline $2.5 \mathrm{~kg}$ zinc/ha & 32.4 & 48.7 & 94.9 & 75.3 & 170.2 \\
\hline $5.0 \mathrm{~kg}$ zinc/ha & 34.8 & 52.6 & 108.9 & 100.3 & 209.2 \\
\hline 5t FYM/ha & 32.5 & 49 & 91.1 & 68.8 & 159.9 \\
\hline $5 \mathrm{t} \mathrm{FYM} \mathrm{+} \mathrm{2.5kg} \mathrm{zinc/ha}$ & 35.4 & 54.1 & 113.8 & 95.9 & 209.7 \\
\hline $5 \mathrm{t} \mathrm{FYM} \mathrm{+} 5.0 \mathrm{~kg}$ zinc/ha & 37.6 & 59 & 125.4 & 115.6 & 241 \\
\hline 10t FYM/ha & 31.1 & 49.4 & 103.7 & 80.8 & 184.5 \\
\hline 10t FYM + 2.5kg zinc/ha & 37.3 & 57 & 131.8 & 116.1 & 247.9 \\
\hline 10t FYM + $5.0 \mathrm{~kg}$ zinc/ha & 39.7 & 62.1 & 146.9 & 138.4 & 285.3 \\
\hline 5t Compost/ha & 32.6 & 49.7 & 95.8 & 74.3 & 170.1 \\
\hline $\begin{array}{l}5 \mathrm{t} \text { Compost }+2.5 \mathrm{~kg} \\
\text { zinc/ha }\end{array}$ & 34.7 & 55.8 & 116.4 & 106.1 & 222.5 \\
\hline $\begin{array}{l}5 t \text { Compost }+5.0 \mathrm{~kg} \\
\text { zinc/ha }\end{array}$ & 38.5 & 59.2 & 136.9 & 128.9 & 265.8 \\
\hline 10t Compost/ha & 33.6 & 50.5 & 106.2 & 83.8 & 190 \\
\hline $\begin{array}{l}10 \mathrm{t} \text { Compost }+2.5 \mathrm{~kg} \\
\text { zinc/ha }\end{array}$ & 37.7 & 58.3 & 127.1 & 119.2 & 246.3 \\
\hline $\begin{array}{l}\text { 10t Compost }+5.0 \mathrm{~kg} \\
\text { zinc/ha }\end{array}$ & 40.5 & 62.5 & 148.9 & 143.7 & 292.6 \\
\hline C.D. at $5 \%$ & 4 & 5.7 & 14 & 15.9 & 25.5 \\
\hline
\end{tabular}

Table 3: Residual effects of zinc and organic manures on rice (third crop) yield and zinc uptake

\begin{tabular}{|c|c|c|c|c|c|}
\hline \multirow[t]{2}{*}{ Treatment } & \multicolumn{2}{|c|}{ Yield $\mathrm{q} / \mathrm{ha}$} & \multicolumn{2}{|c|}{ Zinc uptake g/ha } & \multirow[t]{2}{*}{ Total } \\
\hline & Grain & Straw & Grain & Straw & \\
\hline Control & 16.7 & 34.2 & 30.1 & 64.7 & 94.8 \\
\hline $2.5 \mathrm{~kg}$ zinc/ha & 18.8 & 38.4 & 40.3 & 80.1 & 120.4 \\
\hline $5.0 \mathrm{~kg}$ zinc/ha & 22.5 & 43.9 & 49.8 & 99.1 & 148.9 \\
\hline 5t FYM/ha & 17 & 34.5 & 31.2 & 72.1 & 105.3 \\
\hline $5 \mathrm{t} \mathrm{FYM} \mathrm{+} \mathrm{2.5kg} \mathrm{zinc/ha}$ & 22 & 42.5 & 49.3 & 101.2 & 152.5 \\
\hline $5 t \mathrm{FYM}+5.0 \mathrm{~kg}$ zinc/ha & 24.4 & 49.4 & 58.1 & 126 & 184.1 \\
\hline 10t FYM/ha & 20.4 & 42.1 & 41 & 82.5 & 123.9 \\
\hline 10t FYM + 2.5kg zinc/ha & 23.8 & 46.2 & 51.3 & 110.6 & 163.9 \\
\hline $\begin{array}{l}10 \mathrm{t} F \mathrm{FYM}+5.0 \mathrm{~kg} \\
\text { zinc/ha }\end{array}$ & 25.8 & 52.1 & 64 & 149.2 & 211.2 \\
\hline 5t Compost/ha & 19 & 36.4 & 36.5 & 78.2 & 114.7 \\
\hline $\begin{array}{l}5 \mathrm{t} \text { Compost }+2.5 \mathrm{~kg} \\
\text { zinc/ha }\end{array}$ & 22.3 & 45.6 & 46.3 & 115.7 & 162 \\
\hline $\begin{array}{l}5 \mathrm{t} \text { Compost }+5.0 \mathrm{~kg} \\
\text { zinc/ha }\end{array}$ & 24.2 & 50.3 & 57.6 & 137.5 & 195.1 \\
\hline 10t Compost/ha & 20.7 & 45 & 44.6 & 94.4 & 139 \\
\hline $\begin{array}{l}10 \mathrm{t} \text { Compost }+2.5 \mathrm{~kg} \\
\text { zinc/ha }\end{array}$ & 22.9 & 48.6 & 51.3 & 137.5 & 190.8 \\
\hline $\begin{array}{l}10 \mathrm{t} \text { Compost }+5.0 \mathrm{~kg} \\
\text { zinc/ha }\end{array}$ & 25.8 & 53.4 & 72.5 & 170.7 & 241.2 \\
\hline C.D. at $5 \%$ & 1.2 & 5.1 & 12.1 & 19.6 & 28.8 \\
\hline
\end{tabular}

